\title{
Iheringichthys labrosus (Siluriformes: Pimelodidae) in the Piquiri River, Paraná, Brazil: population structure and some aspects of its reproductive biology
}

\author{
Arlei J. Holzbach ${ }^{1}$, Éder A. Gubiani ${ }^{2}$ and Gilmar Baumgartner ${ }^{2}$
}

\begin{abstract}
The purpose of this study was to analyze the population structure (spatial and temporal distribution, sex ratio, length distribution and length/weight relationship) and reproductive biology of Iheringichthys labrosus. This species is of importance as fisheries resource in the Paraná River basin. Fish were sampled, bimonthly, with gill and trammel nets at three sampling sites (Campina, Apertado and Altônia), located in the Piquiri River, between November 2002 and September 2003. In this study, 164 individuals were collected; the largest capture occurred in Campina site, with 209.88 individuals $/ 1000 \mathrm{~m}^{2}$ of net for 24 hours, while the shift of largest capture was night time $(\mathrm{N})$ and the month was July. Females occurred in larger numbers than males in all periods. The growth was allometric positive and the reproduction period was from the beginning of September to the end of December, with the majority of the individuals showing a standard length between 13.0 and $20.0 \mathrm{~cm}$.

O objetivo deste trabalho foi analisar a estrutura populacional (distribuição espacial e temporal, proporção sexual, distribuição de comprimento e relação peso/comprimento) e a biologia reprodutiva de Iheringichthys labrosus, espécie de importante valor na pesca da bacia do rio Paraná. Os peixes foram coletados bimestralmente, entre novembro de 2002 e setembro de 2003, em três locais de amostragem (Campina, Apertado e Altônia) localizados no rio Piquiri, utilizando-se redes de espera do tipo simples e tresmalhos (emalhar). Nesse estudo foram coletados 164 indivíduos e a maior captura ocorreu no local Campina, com 209,88 indivíduos $/ 1000 \mathrm{~m}^{2}$ de rede por 24 horas, enquanto que o turno de maior captura foi o noturno $(\mathrm{N})$ e o mês foi julho. O crescimento foi alométrico positivo e o período de reprodução foi do início de setembro ao final de dezembro, com a maioria dos indivíduos apresentando comprimento padrão entre 13,0 e 20,0 cm.
\end{abstract}

Key words: Fish reproduction, Population dynamics, Upper Paraná River, Tributary.

\section{Introduction}

Natural stocks of fishes have suffered an appreciable reduction in water courses in Paraná state, especially those species better accepted for human consumption. The causes of this reduction may be attributed to: i) the disordered exploitation of the resources, with the capture of young individuals; ii) overfishing without biological information to help protectionist policies; iii) the increasing intersection of the water courses by dams, which modify the source dynamics, alter the collective spawning areas and interrupt the migration routes of some species; and iv) water pollution by the agricultural, cattle-breeding and industrial activities developed in the basin (Agostinho, 1985). To take rational measures to preserve the natural stocks of fishes and to achieve continuous exploitation, it is necessary to have specific knowledge of their biology and population dynamics. Thus, growth, reproduction and population structure studies supply important information for the management and administration of fish resources (Agostinho et al., 1990).

The knowledge of fish species in a hydrographic basin is the minimal condition for the implementation of any protection policy for water and fishes resources (Agostinho et al., 1990; Holzbach et al., 2005). Among the hydrographic basins situated in the state of Paraná, the Piquiri River represents one of the last environments used by migratory fishes in order to complete their reproductive cycle.

\footnotetext{
${ }^{1}$ Engenheiro de Pesca. arleiholzbach@hotmail.com

${ }^{2}$ Universidade Estadual do Oeste do Paraná - UNIOESTE, Centro de Engenharias e Ciências Exatas, Grupo de Pesquisas em Recursos Pesqueiros e Limnologia, Rua da Faculdade 645, 85903-000 Toledo, Paraná, Brazil. egubiani@yahoo.com.br (EAG), gilmar_baum@yahoo.com.br(GB)
} 
Although studies about the fish fauna in the Piquiri River basin are relatively scarce, some papers can be cited, such as Agostinho et al. (1997a; 2004), who affirm that this river is inhabited by not only migratory species but sedentary species as well, which may or not show parental care. These authors reported the presence of species that do not occur in other environments of the basin, recording the occurrence of 57 species of fishes in this river. Nakatani et al. (1997) analyzed the aspects relative to the ecology of fish eggs and larvae along this basin. Benedito-Cecilio \& Agostinho (2000) studied the distribution, abundance and use of different environments by dominant ichthyofauna in the influence area of Itaipu Reservoir. Gubiani et al. (2006) showed an updated list of the species registered for the Piquiri River, which was complemented by Stanger (2007) in an ichthyofaunistic survey, and Gubiani (2006) that studied the temporal and spatial variations in the composition and abundance of the ichthyofauna in the Piquiri River. Rezende Neto (2004) raised the number of species to approximately 80 and, as stated by this author, Iheringichthys labrosus was the second species in abundance. Recently, Holzbach et al. (2005) analyzed some aspects of the population dynamics of Steindachnerina insculpta (Fernández-Yépez, 1948) in the Piquiri River, and according to Rezende Neto (2004) this species was the most abundant in this river.

The mandi-beiçudo, Iheringichthys labrosus (Lütken, 1874), belongs to the family Pimelodidae and occurs along the entire Prata River basin being abundant in several reservoirs (Burges, 1989). In the Itaipu Reservoir, I. labrosus is a secondary species in commercial fishery importance (Abes et al., 2001). However, it is an important fish species in other reservoirs of the basin, especially Promissão and Água Vermelha Reservoirs (Agostinho et al., 1995; CESP, 1996). Moreover, this species is very important in sport fishing along the Upper Paraná River channel and its main tributaries. Thus, with the end of the trophic upsurge period in the Itaipu Reservoir (Agostinho et al., 1997b), secondary species may become important resources for the commercial fishery, and I. labrosus seems to be one of these species, which has not been well clarified and therefore needing further study in this basin (Kara, 1991).

Despite its wide geographic distribution, only a few studies on I. labrosus have been conducted, mainly concerning in its population structure and reproductive biology. The reproduction of I. labrosus was studied by Silva (1995) in the Camargos Reservoir and Santos et al. (2004) in the Funas Reservoir, both in state of Minas Gerais, Brazil. The diet of $I$. labrosus was studied by Fugi (1993), Fugi et al. (1996) and Abes et al. (2001) in the Upper Paraná River, and Fagundes et al. (2008) in the Ibicuí River. However, in spite of its increasing importance in commercial fishery, studies on the population dynamics and reproductive biology of I. labrosus in the Piquiri River are nonexistent.

Thus, the purpose of this study was to analyze some aspects of the population structure of I. labrosus in the Piquiri River, mainly those referring to the population dynamics (spatial and temporal distribution, sex ratio, length distribution and length/weight relationship) and reproduction.

\section{Material and Methods}

Study Area and Samplings. The Piquiri River basin comprises a drainage area of $31,000 \mathrm{~km}^{2}$. Its sources are located in the São João Mountains, and it runs $485 \mathrm{~km}$ before reaching the Paraná River. The most important tributaries on the north bank are the Goio-erê, Tricolor and Cantú Rivers, and for the south bank these are the Sapucaí and Melissa Rivers (Paiva, 1982). The Piquiri River shows several rapids, small falls and narrow stretches, with a length of more than $1,000 \mathrm{~m}$ from source to mouth (Agostinho \& Júlio Jr., 1999).

Fish were collected bimonthly during six samplings between November 2002 and September 2003, at three sampling sites located in the Piquiri River (Campina, Apertado and Altônia) (Fig. 1).

Samplings were conducted with gill (mesh size of 2.4, 3.0, 4.0, 5.0, 6.0, 7.0, 8.0, 9.0, 10.0, 12.0, 14.0 and $16.0 \mathrm{~cm}$ between opposite knots) and trammel (with inner mesh size of 6.0, 7.0, and $8.0 \mathrm{~cm}$ between opposite knots) nets. Nets remained set for 24 hours and checked every 8 hours. The captured individuals were stored in plastics bags, identified with regard to mesh size and stored in ice in the field, for further laboratory analyses. Individuals were identified according to Graça \& Pavanelli (2007). Voucher specimens were deposited in the Ichthyological Collection of the Núcleo de Pesquisas em Limnologia, Ictiologia e Aqüicultura (Nupelia), of Maringá State University (NUP 671).

Recorded for each individual were total length $\left(\mathrm{L}_{\mathrm{t}}\right)$, standard length $\left(\mathrm{L}_{\mathrm{s}}\right)$, total weight $\left(\mathrm{W}_{\mathrm{t}}\right)$, gonadal weight $\left(\mathrm{W}_{\mathrm{g}}\right)$ and gonadal development stage, and some additional data were gathered as well (date, place, mesh size and capture time).

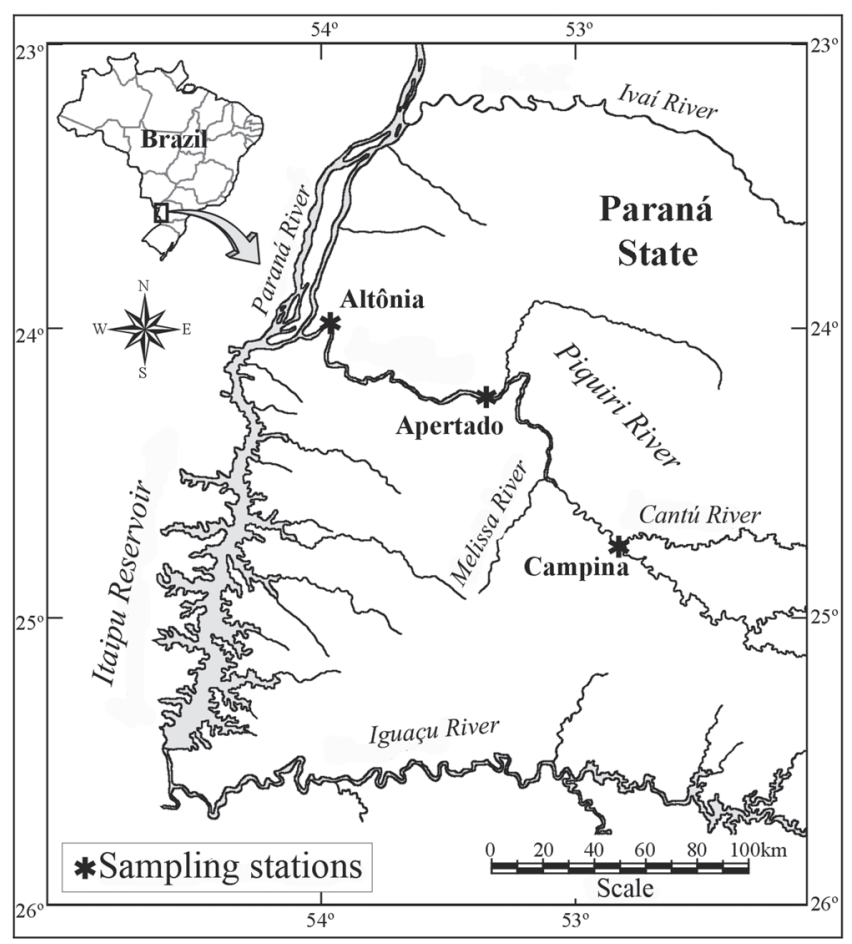

Fig. 1. Localization of the sampling sites in the Piquiri River. 
The length data were collected in centimeters $(\mathrm{cm})$ and weight in grams $(\mathrm{g})$.

Population structure. Spatial and temporal distribution of the individuals' abundance were indexed by the catch per unit of effort (CPUE) in number (individuals $/ 1000 \mathrm{~m}^{2}$ of net for 24 hours) and weight ( $\mathrm{kg} / 1000 \mathrm{~m}^{2}$ of net for 24 hours), as proposed by King (1995). Sex ratio was determined by the bimonthly and total frequencies of males and females collected. The chi-square test $\left(\chi^{2}\right)$ at a significance level of $5 \%$ was applied to determine significant differences from the expected proportion (1:1) (Vazzoler, 1996).

For the length distribution analysis, the individuals were separated into 21 classes of standard length $\left(\mathrm{L}_{\mathrm{s}}\right)$ with $1.0 \mathrm{~cm}$ intervals. Length/weight relationship was established according to Santos (1978) and the weight and length data were adjusted to the potential equation $\mathrm{W}_{\mathrm{t}}=\mathrm{a}^{*} \mathrm{~L}_{\mathrm{s}}^{\mathrm{b}}$, where $\mathrm{W}_{\mathrm{t}}$ is the total weight, $\mathrm{L}_{\mathrm{s}}$ is the standard length, "a" is the condition factor coefficient and "b" is the angular coefficient that allows the determination of growth.

Length/weight relationship parameters were determined using Statistica ${ }^{\mathrm{TM}}$ software for Windows 7.1, by adjusting the parameters by nonlinear regression using the minimum squares method with the Gauss-Newton algorithm, which is an interactive process that requires initial values (seeds) for the parameters to be estimated (Myers, 1990).

To test the differences between the parameters of the adjusted curves for males and females, ANCOVA at the significance level of 5\% (Goldberg \& Scheiner, 1993) was applied to the linear regression parameters of the standard length and total weight, $\log$-transformed $(\log 10)$.

Nutritional dynamics. the condition factor (K) (Le Cren, 1951) is a quantitative indicator of degree of fish welfare, reflecting recent feeding conditions. Thus, the condition factor was estimated according to Vazzoler (1996) for each individual through the expression,

$$
\mathrm{K}=\frac{\mathrm{W}_{\mathrm{t}}}{\mathrm{L}_{\mathrm{t}}^{\mathrm{b}}}
$$

where $b$ is the angular coefficient of the length/weight relationship, $\mathrm{W}_{\mathrm{t}}$ is the total weight and $\mathrm{L}_{\mathrm{t}}$ is the total length.

Fullness index (FI) (Zavala-Camin, 1996), which may be used to recognize the feeding rhythm throughout the cycles, was calculated for each individual by the following expression,

$$
\mathrm{FI}=\frac{\mathrm{W}_{\mathrm{e}}}{\mathrm{W}_{\mathrm{t}}} \times 100
$$

where $\mathrm{W}_{\mathrm{e}}$ is the stomach weight.

Reproduction. The gonadal development stage was determined for both sexes, using the method proposed by Vazzoler (1996), where four maturity stages were established: immature, maturation, reproduction and rest. The gonadosomatic index (GSI), used to infer the reproductive cycle, was calculated in accordance with Vazzoler (1996), by the following expression,

$$
\mathrm{GSI}=\frac{\mathrm{W}_{\mathrm{g}}}{\mathrm{W}_{\mathrm{t}}} \times 100
$$

where $\mathrm{W}_{\mathrm{g}}$ is the gonadal weight.

\section{Results}

During the samplings, 164 individuals of I. labrosus were captured, which corresponded to $9.84 \%$ of the individuals captured during the ichthyofaunistic complementation survey accomplished by Rezende Neto (2004).

The spatial and temporal distribution of I. labrosus analyzed through the catch by unit effort (CPUE) showed that Campina (headwater) was the most representative site, in number of individuals (40.19 individuals $/ 1000 \mathrm{~m}^{2}$ of net for 24 hours) as well as in biomass $\left(3.50 \mathrm{~kg} / 1000 \mathrm{~m}^{2}\right.$ of net for 24 hours), followed by the Altônia site (mouth) with 4.31 individuals $/ 1000 \mathrm{~m}^{2}$ of net for 24 hours and $0.42 \mathrm{~kg} / 1000 \mathrm{~m}^{2}$ of net for 24 hours in biomass, and Apertado (middle) with 2.58 individual $/ 1000 \mathrm{~m}^{2}$ of net for 24 hours, and biomass of 0.31 $\mathrm{kg} / 1000 \mathrm{~m}^{2}$ of net for 24 hours (Figs. 2a,b).

The highest capture based on shift was observed in the evening, with 27.85 individuals $/ 1000 \mathrm{~m}^{2}$ of net for 24 hours and biomass of $2.70 \mathrm{~kg} / 1000 \mathrm{~m}^{2}$ of net for 24 hours (Figs. $2 \mathrm{c}, \mathrm{d})$, followed by the morning, with 17.80 individuals/1000 $\mathrm{m}^{2}$ of net for 24 hours, and biomass of $1.38 \mathrm{~kg} / 1000 \mathrm{~m}^{2}$ of net for 24 hours and afternoon with 1.43 individuals $/ 1000 \mathrm{~m}^{2}$ of net for 24 hours and biomass of $0.15 \mathrm{~kg} / 1000 \mathrm{~m}^{2}$ of net for 24 hours (Figs. 2c,d).

Temporal variation in the captures showed a clear seasonal separation. Captures were more abundant between May and September, with the largest values of CPUE in July (45.94 individuals $/ 1000 \mathrm{~m}^{2}$ of net for 24 hours and biomass of 4.29 $\mathrm{kg} / 1000 \mathrm{~m}^{2}$ of net for 24 hours), followed by May (26.99 individuals $/ 1000 \mathrm{~m}^{2}$ of net for 24 hours and biomass of $2.29 \mathrm{~kg} /$ $1000 \mathrm{~m}^{2}$ of net for 24 hours) and September (8.61 individuals/ $1000 \mathrm{~m}^{2}$ of net for 24 hours and biomass of $0.86 \mathrm{~kg} / 1000 \mathrm{~m}^{2}$ of net for 24 hours) (Figs. 2e,f).

Females occurred more often than males in every sampled month, but because of the small number of fish caught in some months $(\mathrm{n}<20)$, only the total sex ratio was tested. Thus, the total sex ratio showed a significant difference at the 5\% level, compared to the expected proportion (1:1) (Table 1).

Length class analysis showed that the majority of the individuals had lengths between 13.0 and $20.0 \mathrm{~cm}$ (Fig. 3), with approximately $70 \%$ of the individuals in these classes. The minimum and maximum values were 8.5 and $28.5 \mathrm{~cm}$, respectively. The mean ( \pm standard deviation) was $17.05 \pm 3.24$ $\mathrm{cm}$.

Length/weight relationship was analyzed for each sex (Fig. 4). The relation found was $\mathrm{W}_{\mathrm{t}}=0.00981 * \mathrm{~L}_{\mathrm{s}}^{3.1842}$ for females and $\mathrm{W}_{\mathrm{t}}=0.01165^{*} \mathrm{~L}_{\mathrm{s}}^{3.1225}$ for males (Figs. 4a,b). As determined 

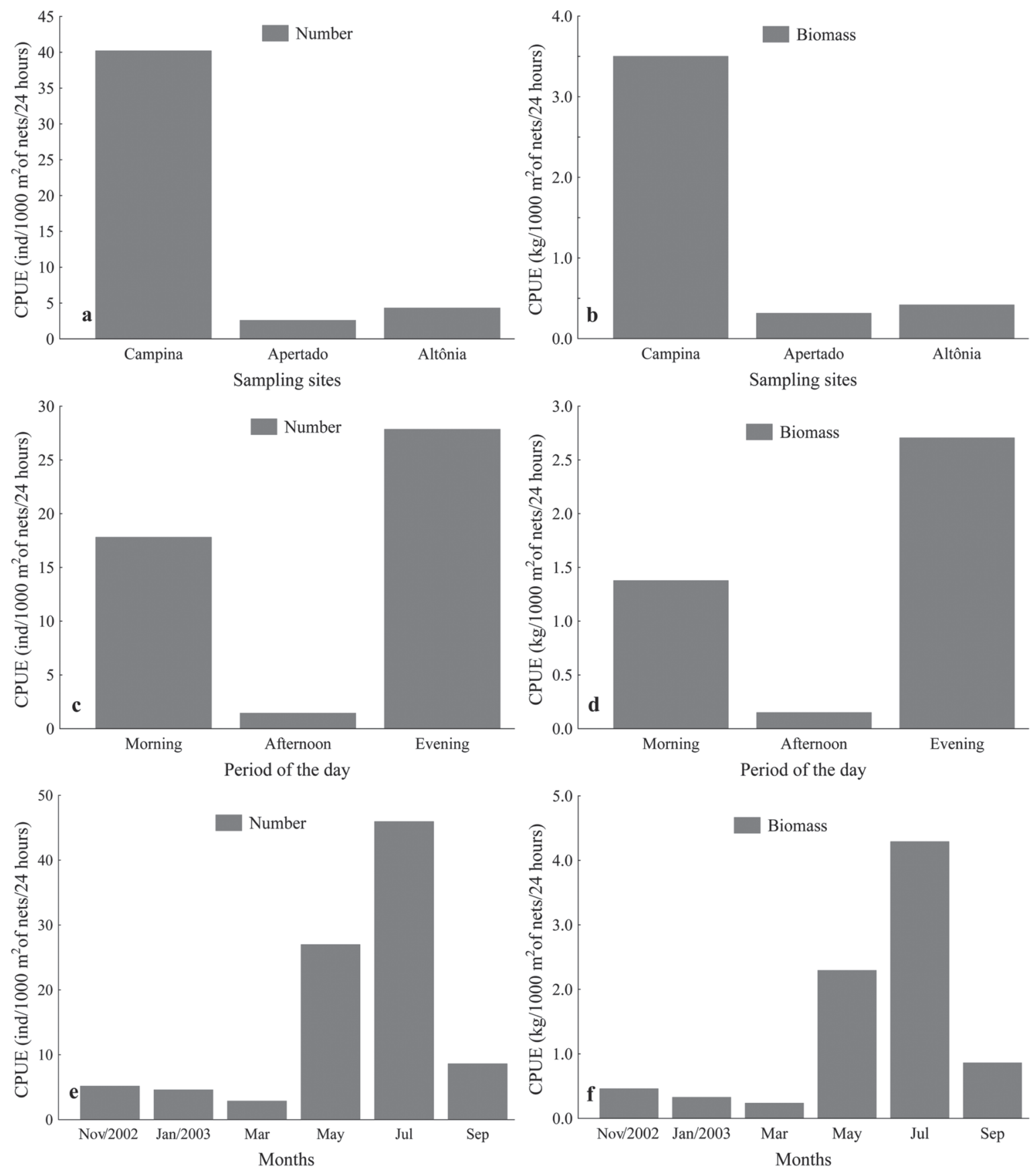

Fig. 2. Catch per unit of effort, in number and biomass (number of individuals and $\mathrm{kg} / 1000 \mathrm{~m}^{2}$ of net for 24 hours) of Iheringichthys labrosus, obtained at the sampling sites ( $\mathrm{a}$ - number of individuals, $\mathrm{b}$ - biomass); shifts (c - number of individuals, $\mathrm{d}$ - biomass) and months ( $\mathrm{e}$ - number of individuals, $\mathrm{f}$ - biomass) in the Piquiri River from November 2002 to September 2003.

Table 1. Sex ratio of Iheringichthys labrosus and the chi-square test $\left(\chi^{2}\right)$ from November 2002 to September 2003 in the Piquiri River. $\mathrm{N}=$ number of captured individuals. $*=$ relative to $5 \%$ level, $\chi_{0.05}^{2}=3.841$.

\begin{tabular}{lcccccc}
\hline \multirow{2}{*}{ Month } & \multicolumn{2}{c}{ Females } & \multicolumn{2}{c}{ Males } & Total & \\
\cline { 2 - 6 } & $\mathrm{N}$ & $\%$ & $\mathrm{~N}$ & $\%$ & & $\chi_{0.05}^{2}$ \\
\hline November/2002 & 8 & 88.89 & 1 & 11.11 & 9 & \\
January/2003 & 5 & 62.50 & 3 & 37.50 & 8 & \\
March & 4 & 100.00 & 0 & 0.00 & 4 & \\
May & 33 & 71.74 & 13 & 28.26 & 46 & \\
July & 56 & 72.73 & 21 & 27.27 & 77 & \\
September & 8 & 53.33 & 7 & 46.67 & 15 & \\
\hline TOTAL & 114 & 71.70 & 45 & 28.30 & 159 & $29.94^{*}$ \\
\hline
\end{tabular}




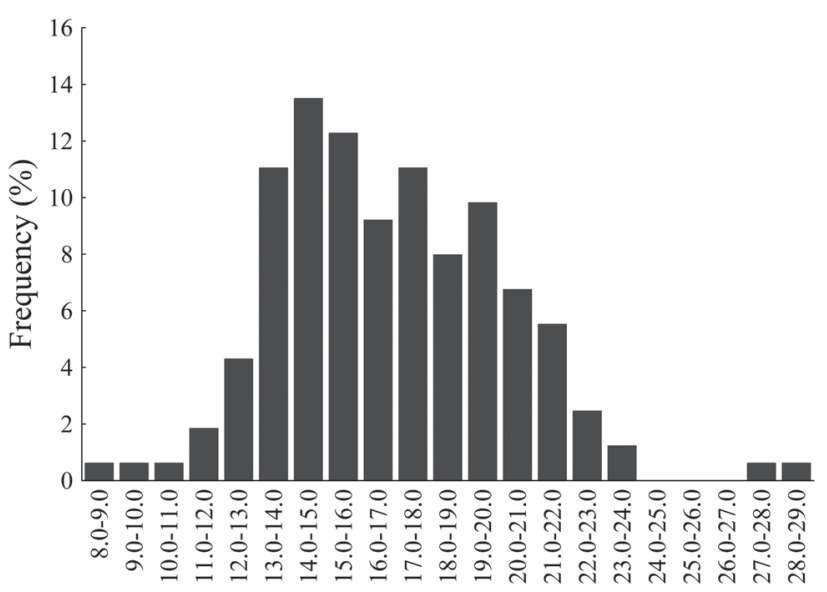

Standard lenght classes $(\mathrm{cm})$

Fig. 3. Length distribution of Iheringichthys labrosus captured in the Piquiri River from November 2002 to September 2003.

by ANCOVA, the allometric coefficient which is related to the growth form of the individuals did not show significant differences between the sexes $(p=0.32)$, while the parameter " $\phi$ " which is related to the fattening degree showed significant differences $(p=0.0001)$, and the females showed a better coefficient of condition factor. Thus, only one relationship was considered, represented by $\mathrm{W}_{\mathrm{t}}=0.00975^{*} \mathrm{~L}_{\mathrm{s}}^{3.1882}$, valid for both sexes (Fig. 4c).

Nutrition Dynamics. The condition factor for females showed little variation between November 2002 and May 2003 (mean $\mathrm{K}=0.95$ ); however, in July it was substantially increased $(\mathrm{K}=1.09)$, with a subsequent reduction, with the lowest value observed in September $2003(\mathrm{~K}=0.90)$ (Fig. $5 \mathrm{a})$. For males, the condition factor was highest in November $2002(\mathrm{~K}=1.37)$; however, in January, May, July and September 2003, the variation of this parameter was minimal (mean $\mathrm{K}=1.15$ ). There is a discontinuity in the values of the condition factor for males in March, due to the absence of individuals in this sampling (Fig. 5b).

The fullness index for females was highest in January, May and July 2003 (0.82; 0.74 and 0.74 , respectively) and lowest in November 2002 and March 2003 (0.46 and 0.39, respectively) (Fig. 6a). For males, the highest value was observed in May 2003 (0.79) and the lowest in September 2003 (0.39) (Fig. 6b).

Reproduction. Regarding the gonadal development stage, it was possible to observe that the largest frequencies of individuals in rest were seen in March (75\%), May (71.74\%) and July $(68.05 \%)$, which indicates that reproduction ended in this period (Fig. 7). After this month, there was an increase in individuals in the maturation process and reduction of those at rest, where July (30.56\%) and September (45\%) showed the highest values for maturation.

The greatest frequency of individuals in reproduction occurred in November (77.78\%), as observed in Fig. 7. In
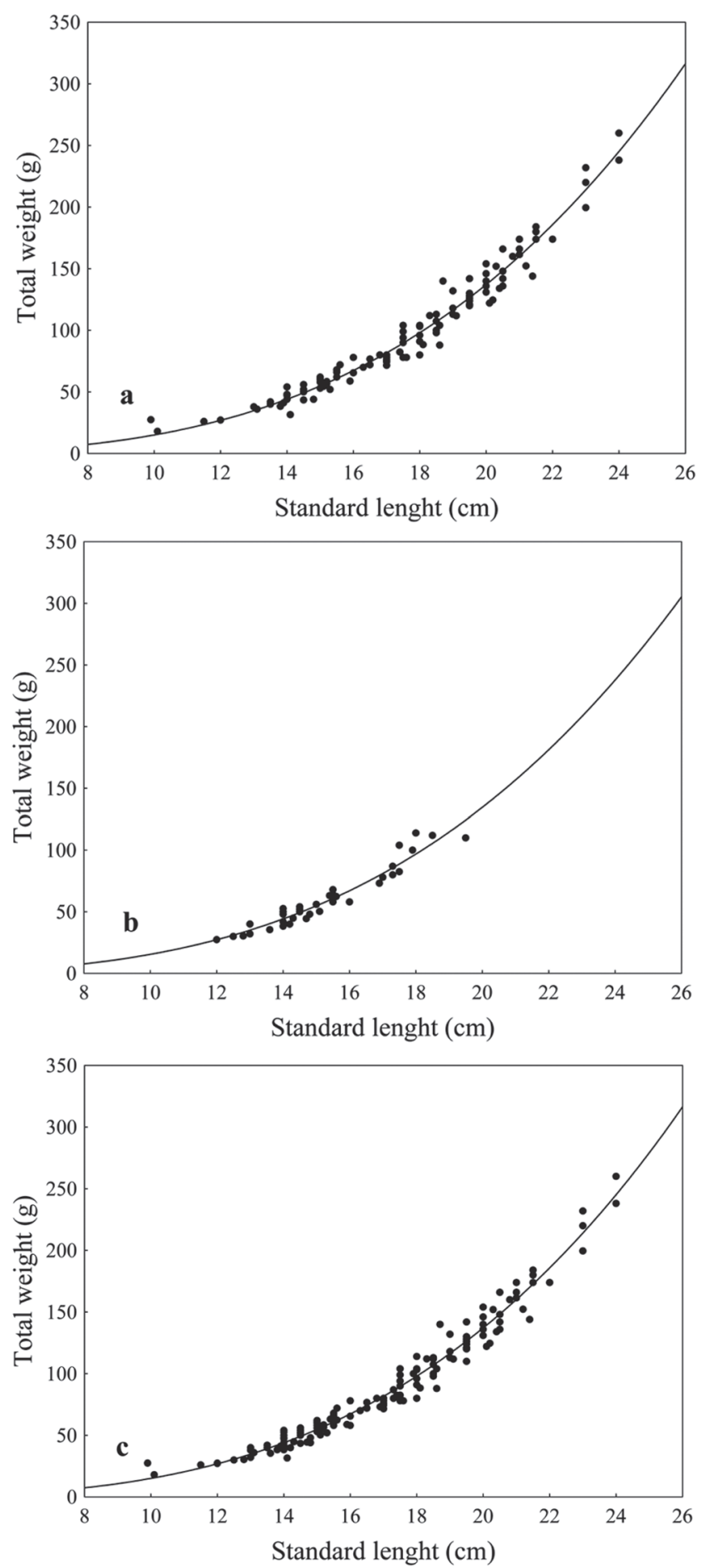

Fig. 4. Length/weight relationship for females (a), males (b) and for both sexes (c) of Iheringichthys labrosus, obtained between November 2002 and September 2003 in the Piquiri River.

January, there was a decrease in the number of individuals in reproduction $(35 \%)$, and increase in individuals in maturation $(50 \%)$. Thus, it is possible to conclude that the reproductive period for this species seems to start in the beginning of September extending to the end of January, with a reproduction peak in November. 

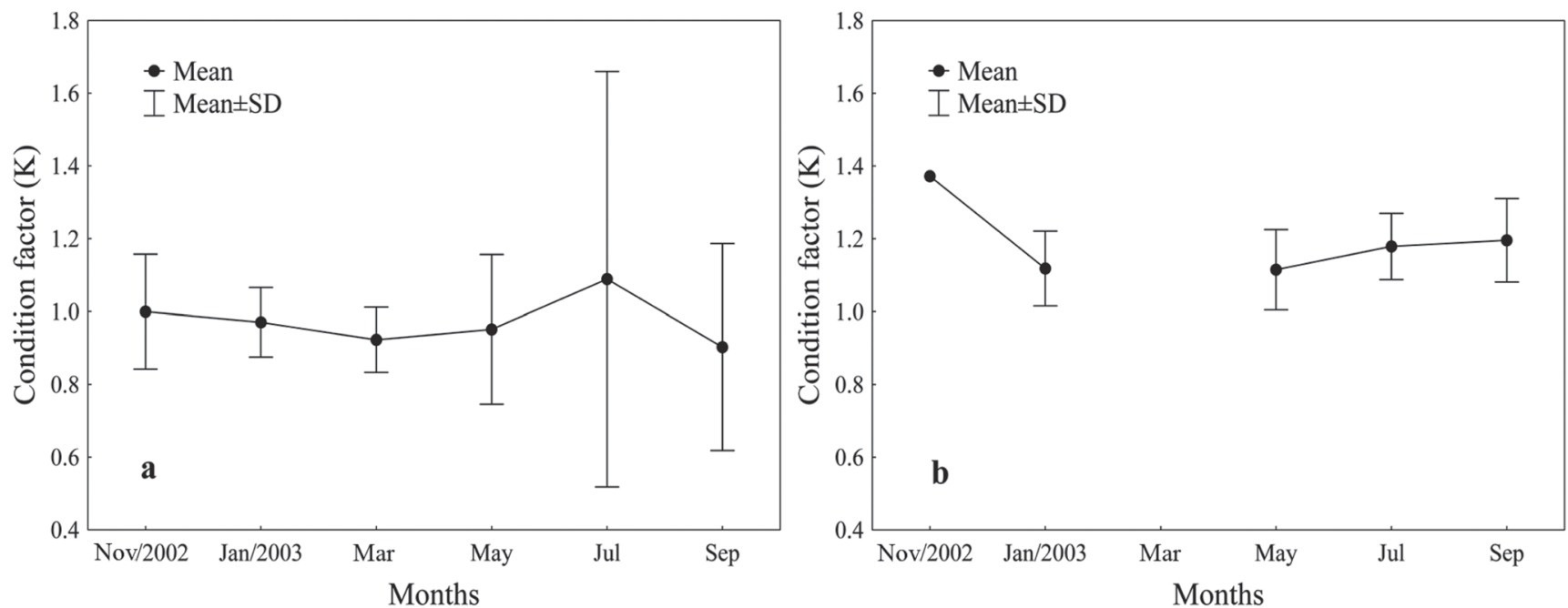

Fig. 5. Bimonthly variation of the mean values of the condition factor for females (a) and males (b) of Iheringichthys labrosus in the Piquiri River from November 2002 to September 2003. ( $\mathrm{SD}=$ Standard deviation).
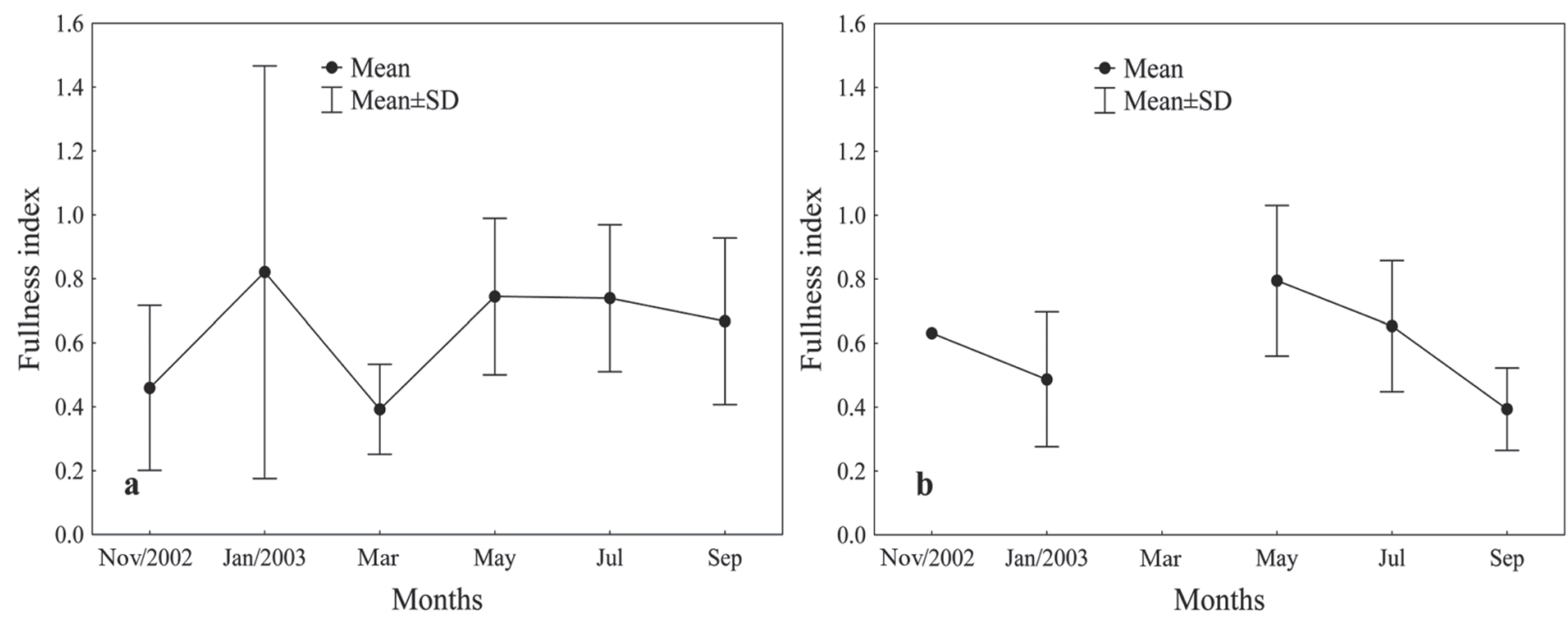

Fig. 6. Bimonthly variation of the mean values of the fullness index (FI) of females (a) and males (b) of Iheringichthys labrosus in the Piquiri River from November 2002 to September 2003. (SD = Standard deviation).

The gonadosomatic index for females showed the greatest value in November 2002 (3.12) and September 2003 (4.79) (Fig. 8a), a period that seems to be the reproduction time. Although males showed the highest index in July 2003 (1.07) (Fig. 8b), it is not evident that they had the same reproduction periodicity found for females.

\section{Discussion}

Studies concerning the population structure of fishes are very important because they provide many elucidating answers about species ecology (Agostinho et al., 1994). Several aspects of the life strategy of the species about energy allocation for growth, reproduction or maintenance are interpreted through the analyses of population structure (Benedito-Cecílio \& Agostinho, 1997).

In the upper Paraná River floodplain, I. labrosus is a benthophagous species (Fugi, 1993; Fugi et al., 1996; Peretti \& Andrian, 2004), living close to the bottom. Thus, the largest abundance of I. labrosus found at the Campina site could be associated with the characteristics of that site and with the feeding habit of the species. According to Holzbach et al. (2005), the largest capture of Steindachnerina insculpta, also found at the Campina site, would be related to the presence of the Cantú River mouth which has conditions that support its development, such as vast marginal vegetation, calm and clear water and low depth, which would characterize an ideal habitat for the species. Ploskey (1985) considered that the presence of large amounts of submerged vegetation creates ideal habitats for the development of the benthonic community, facilitating the feeding of I. labrosus.

The high capture of I. labrosus recorded in the Piquiri River in the evening does not seem to be associated with the feeding habit of this species. According to Fugi (1993) and 
Fugi et al. (1996), I. labrosus in the upper Paraná River floodplain shows greater feeding activity at dawn and during the diurnal period, a finding also reported by Fagundes et al. (2008) in the Ibicuí River in southern Brazil. Thus, the largest capture observed in the evening may be related to other factors, such as physical and chemical conditions of the water, and shelter availability, among others, which were not examined in this study.

The largest captures obtained in May and July may be related to the period that precedes reproduction. According to Vazzoler (1996), I. labrosus is considered a migratory species of short distances, and thus, the largest capture observed in the Cantú River mouth, a higher location in the longitudinal gradient of the Piquiri River, could also be related to the fact that the species has short reproductive migrations, increasing its abundance in the months that precede the reproduction.

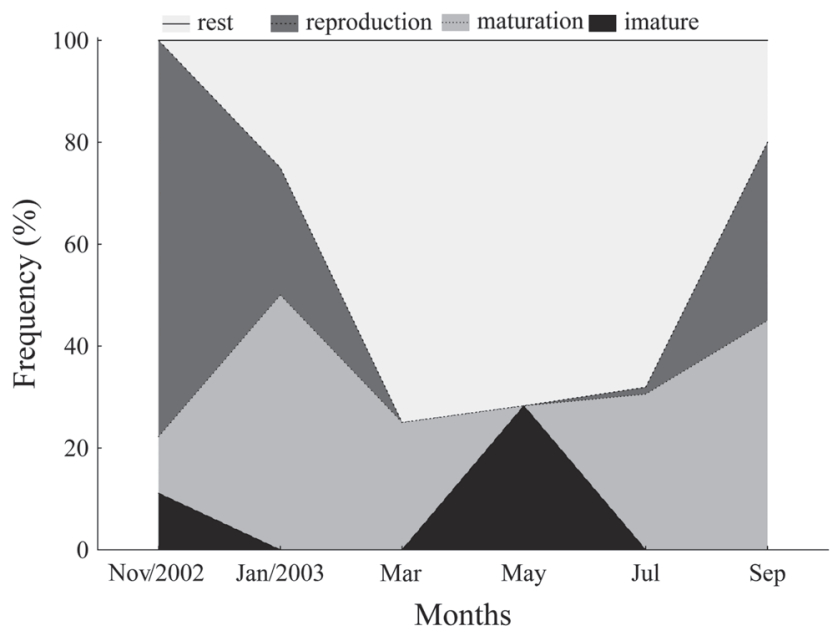

Fig. 7. Frequency of the gonadal development stage of Iheringichthys labrosus captured in the Piquiri River from November 2002 to September 2003.

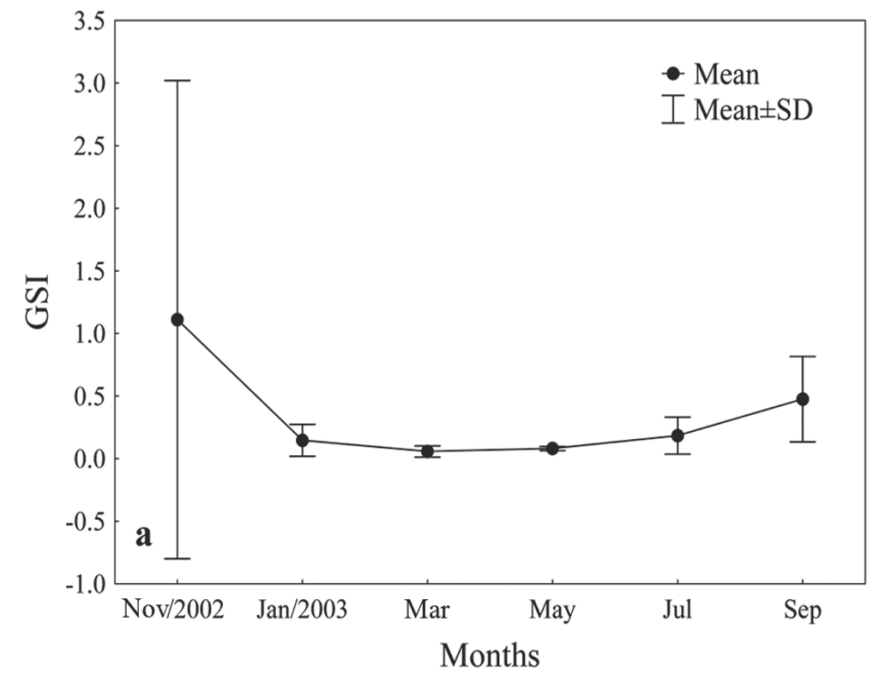

According to Vazzoler (1996), the sex ratio of fishes varies along the life cycle due to successive events that act in a different way on the individuals of each sex, for example, mortality. This author stated that this analysis supplies important information for the characterization of population structure, besides providing information for the study of other aspects, such as the evaluation of reproductive potential and stock size estimates. Sex population structure may represent an adaptation to food supply, where there is a prevalence of females when the available food is abundant (Nikolskii, 1969). Silva (1995), in studying biological aspects of I. labrosus in the Camargos Reservoir, state of Minas Gerais, observed a prevalence of females in the total samplings, except in the spring, when the proportion approached 1:1, indicating space segregation between males and females. In our study, as demonstrated in Table 1, a similar tendency was observed. However, because of the small number of catches in some months, the differences could not be tested.

Iheringichthys labrosus is considered a small- to mediumsize species with a maximum length of $26.8 \mathrm{~cm}$ (Vazzoler, 1996). In this study, $70 \%$ of the individuals showed a medium size, between 13.0 and $20.0 \mathrm{~cm}$. In addition, the largest recorded individual was $28.5 \mathrm{~cm}$, reaching a maximum size greater than that found by Vazzoler (1996) in the upper Paraná River floodplain.

The weight/length relationship can offer important information about a population because it describes structural characteristics of the individuals within the population (Le Cren, 1951; Kohler et al., 1995). In the weight/length relationship, the coefficient $b$ is considered a measure of relative growth, also reflecting recent feeding conditions (Le Cren, 1951). According to Benedito-Cecílio \& Agostinho (1997), if the growth coefficient (b) is equal to three, the growth is called isometric (the weight increments follow length-wise growth), if $b$ is more than three, growth is allometric positive (there is an increment in weight larger than in length), and if it

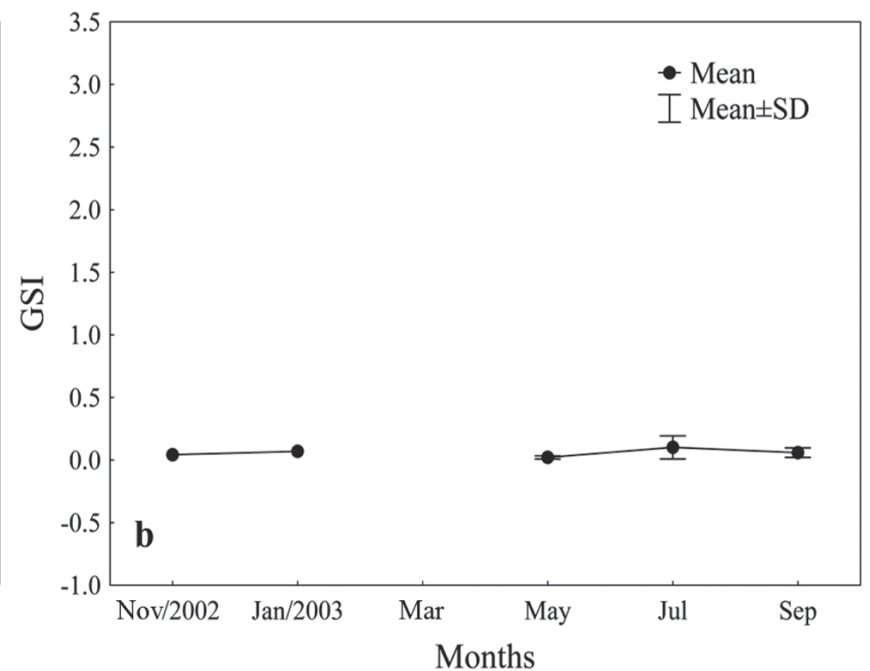

Fig. 8. Bimonthly variation of the mean values of the gonadosomatic index (GSI) of females (a) and males (b) of Iheringichthys labrosus in the Piquiri River from November 2002 to September 2003. (SD = Standard deviation). 
is less than three, growth is allometric negative (there is an increment in weight smaller than in length). In agreement with our results, I. labrosus showed a positive allometric growth, because the growth coefficient (b) was 3.1882. Thus, in agreement with Araújo \& Vicentini (2001), I. labrosus showed a growth coefficient greater than three. It may be considered a round fish, with a larger increase in weight than in length. In the Camargos Reservoir, state of Minas Gerais, the females of I. labrosus showed a larger allometric coefficient when compared to males (Silva, 1995). The present study corroborates those results; however, statistical differences were not observed between the sexes regarding this coefficient. According to Rossi-Wongtschowski (1977), the length/weight relationship in fish may or may not show sexual dimorphism.

Factors such as gonadal and stomach weight may affect the variations of the general conditions of the fish's "welfare," because these conditions depend on the gonadal development stage and the feeding activity at the time of their capture (Agostinho et al., 1990). The fullness index shows a quantitative character and it may supply more reliable information to indicate the period when the fish have a greater feeding activity (Barbieri, 1992). The decrease in the mean values of the fullness index for females during the reproductive period may be explained by the fact that many species reduce feeding intensity during that period (Barbieri \& Barbieri, 1984), as consequence of the considerable increase in gonadal size and consequent reduction of the coelomic space by the stomach, leading to a decrease in feeding rate of the fish (Chatterji et al., 1979). This was corroborated in this study, where the lowest fullness indexes were recorded in the reproduction period.

The condition factor, which is related to annual cyclical changes in gonad development, growth and accumulation of fat, stomach repletion and environmental variations (Barbieri \& Verani, 1987), and the gonadosomatic index, which reflects the development of the ovaries as percentage of total weight (Vazzoler et al., 1989), can both indicate the spawning period. The bimonthly variation analysis of the mean values of the gonadosomatic index revealed that the species has a reproductive period between September and December, while the condition factor showed a larger value in July for females and in November for males. Thus, the condition factor for the species studied may be considered a good indicator of the reproduction period because it is larger in the period that precedes the greatest reproductive activity. This indicates an accumulation of reserves to accomplish reproduction, and by decreasing drastically during that period, caused by the expenditure of energy in such activity. Similar behavior was observed by Le Cren (1951), Rossi-Wongtschowski (1977), Isaac-Nahum \& Vazzoler (1983); Barbieri $(1992,1995)$ and Silva et al. $(2005 ; 2007)$ in other fish species. The analysis of gonadal maturation confirm the above findings, indicating that the reproductive period of the species begins in September and extends to the end of December, with a peak in November.

The reproductive period of I. labrosus determined in this study (from September to December) corroborates that re- ported by Vazzoler (1996), which reveals that spawning occurs in this period for most of the fish species in the Paraná River basin; this period coincides with the highest temperatures and rainfall, which act as triggers for spawning. Santos et al. (2004) studied I. labrosus in the Furnas Reservoir and tributaries in the state of Minas Gerais and found similar results, with a reproductive period from October to January and the highest condition factor in the period that precedes reproduction, decreasing during the same period. Silva (1995) demonstrated that the highest reproductive activity for $I$. labrosus in the Camargos Reservoir, state of Minas Gerais, occurred in the spring (September to December). Therefore, it is evident that the reproductive period for this species is well defined and occurs at the same time in different environments.

In summary, this work shows that the greatest abundance for I. labrosus, in both number and biomass, was obtained in the headwater (Campina site), during the evening and in May and July. The sex ratio showed a prevalence of females in the total samplings. There were no differences in length/weight relationships. The reproductive period, based on condition factor, gonadosomatic index and gonadal maturation, was from September to December. Regarding the conservation of the species in the Piquiri River, our study suggests that these aspects could be important for preservation and management.

\section{Acknowledgments}

We thank the Instituto Ambiental do Paraná (IAP - Paraná State), for supporting the collection of biological material, and Itaipu Binational for financial support.

\section{Literature Cited}

Abes, S. da S., A. A. Agostinho, E. K. Okada \& L. C. Gomes. 2001. Diet of Iheringichthys labrosus (Pimelodidae, Siluriformes) in the Itaipu Reservoir, Paraná River, Brazil-Paraguay. Brazilian Archives of Biology and Technology, 44(1): 101-105.

Agostinho, A. A. 1985. Estrutura da população, idade, crescimento e reprodução de Rhinelepis aspera (Agassiz, 1829) (Osteichthyes, Loricariidae) do rio Paranapanema, PR. Unpublished Ph.D. Dissertation, Universidade Federal de São Carlos, São Carlos. 231p.

Agostinho, A. A., G. Barbieri, J. R. Verani \& N. S. Hahn. 1990. Variação do fator de condição e do índice hepatossomático e suas relações com o ciclo reprodutivo em Rhinelepis aspera (Agassiz, 1829) (Osteichthyes, Loricariidae) no Rio Paranapanema, Porecatu, PR. Ciência \& Cultura, 42(9): 711714.

Agostinho, A. A., E. Benedito-Cecilio, L. C. Gomes \& A. A. Sampaio. 1994. Spatial and temporal distribution of sardela, Hypophthalmus edentatus (Pisces, Siluroidei), in the area of influence of the Itaipu reservoir (Paraná, Brazil). Revista Unimar, 16(supl. 3): 27-40.

Agostinho, A. A., L. M. Bini, L. C. Gomes, H. F. Júlio Jr., C. S. Pavanelli \& C. S. Agostinho. 2004. Fish assemblages. Pp. $223-$ 246. In: Thomaz, S. M., A. A. Agostinho \& N. S. Hahn (Eds.). The Upper Paraná River and its Floodplain: physical aspects, ecology and conservation. Leiden, Backhuys Publishers. 393p. 
Agostinho, A. A., N. S. Hahn, L. C. Gomes \& L. M. Bini. 1997 b. Estrutura trófica. Pp. 229-248. In: Vazzoler, A. E. A. de M., A. A. Agostinho \& N. S. Hahn (Eds.). A planície de inundação do alto rio Paraná: aspectos físicos, biológicos e sócio-econômicos. Maringá, EDUEM. 460p.

Agostinho, A. A. \& H. F. Júlio Jr. 1999. Peixes da bacia do alto rio Paraná. Pp. 374-400. In: Lowe-McConnell, R. H. (Ed.). Ecologia de comunidades de peixes tropicais. São Paulo, EDUSP. $534 \mathrm{p}$.

Agostinho, A. A., H. F. Júlio Jr., L. C. Gomes, L. M. Bini \& C. S. Agostinho. 1997a. Composição, abundância e distribuição espaço-temporal da ictiofauna. Pp. 180-228. In: Vazzoler, A. E. A. de M., A. A. Agostinho \& N. S. Hahn (Eds.). A planície de inundação do alto rio Paraná: aspectos físicos, biológicos e sócio-econômicos. Maringá, EDUEM. 460p.

Agostinho, A. A., A. E. A de M. Vazzoler \& S. M. Thomaz. 1995. The high River Paraná Basin: limnological and ichthyological aspects. Pp. 59-103. In: Tundisi, J. G, C. E. M. Bicudo \& T. Matsumura-Tundisi (Eds.). Limnology in Brazil. Rio de Janeiro, Brazilian Academy of Sciences, Brazilian Limnological Society. 376p.

Araújo, F. G. \& R. N. Vicentini. 2001. Relação peso-comprimento da corvina Micropogonias furnieri (Desmarest) (Pisces, Sciaenidae) na Baía de Sepetiba, Rio de Janeiro. Revista Brasileira de Zoologia, 18(1): 133-138.

Barbieri, G. 1992. Dinâmica da nutrição de Astyanax scabripinnis paranae (Characiformes, Characidae) do Ribeirão do Fazzari: São Carlos, SP. Revista Brasileira de Zoologia, 21(1): 68-72.

Barbieri, G. 1995. Biologia populacional de Cyphpocharax modesta (Characiformes, Curimatidae) da Represa do Lobo, Estado de São Paulo. II- Dinâmica da reprodução e influência de fatores abióticos. Boletim do Instituto de Pesca, 22(2): 57-62.

Barbieri, G. \& M. C. Barbieri. 1984. Note on nutritional dynamics of Gymnotus carapo (L.) from the Lobo Reservoir, São Paulo State, Brazil. Journal of Fish Biology, 24: 351-355.

Barbieri, G. \& J. R. Verani. 1987. O fator de condição como indicador do período de desova em Hypostomus aff. plecostomus (Linnaeus, 1758) (Osteichthyes, Loricariidae), na represa do Monjolinho (São Carlos, SP). Ciência \& Cultura, 39(7): 655658.

Benedito-Cecílio, E. \& A. A. Agostinho. 1997. Estrutura das populações de peixes do reservatório de segredo. Pp. 113-139. In: Agostinho, A. A. \& L. C. Gomes (Eds.). Reservatório de Segredo: bases ecológicas para o manejo. Maringá, EDUEM. 387p.

Benedito-Cecilio, E. \& A. A. Agostinho. 2000. Distribution, abundance and use of different environments by dominant ichthyofauna in the influence area of the Itaipu Reservoir. Acta Scientiarum, 22(2): 429-437.

Burges, W. E. 1989. Na atlas of freshwater and marine catfishes a preliminary survey of the Siluriformes. New Jersey, T. F. H. Publications. 784p.

CESP (Companhia Energética de São Paulo). 1996. Aspectos limnológicos, ictiológicos e pesqueiros de reservatórios da CESP no período de 1986 a 1994. CESP-Série Pesquisa e Desenvolvimento, São Paulo, 136. 81p.

Chatterji, A., A. Q. Siddiqui \& A. A. Khan. 1979. Studies on the age and growth of the Bata, Labeo bata (Ham.) (Cyprinidae, Teleostei) from the river Kali, India. Hydrobiologia, 63(2): 167176.

Fagundes, C. K., E. R. Behr \& C. B. Kotzian. 2008. Diet of Iheringichthys labrosus (Siluriformes, Pimelodidae) in the Ibicuí River, Southern Brazil. Iheringia, Série Zoologia, 98(1): 60-65.
Fugi, R. 1993. Estratégias alimentares utilizadas por cinco espécies de peixes comedoras de fundo do alto Rio Paraná/PR-MS. Unpublished M.Sc. Dissertation, Universidade Federal de São Carlos, São Carlos. 142p.

Fugi, R., N. S. Hahn \& A. A. Agostinho. 1996. Feeding styles of five species of bottom-feeding fishes of the high Paraná River. Environmental Biology of Fishes, 46: 297-307.

Goldberg, D. E. \& S. M. Scheiner. 1993. ANOVA and ANCOVA: Field Competition Experiments. Pp. 69-93. In: Scheiner, S. M. \& J. Gurevitch (Eds.). Design and Analysis of Ecological Experiments. New York, Chapman \& Hall. 445p.

Graça, W. J. \& C. S. Pavanelli. 2007. Peixes da planície de inundação do alto Rio Paraná e áreas adjacentes. Maringá, EDUEM. 308 p.

Gubiani, E. A. 2006. Variações espaciais e temporais na composição e abundância da ictiofauna do rio Piquiri. Unpublished Ph.D. Monographs, Universidade Estadual de Maringá, Maringá. 31p.

Gubiani, E. A., A. J. Holzbach, G. Baumgartner, L. B. Rezende Neto, F. Bergmann. 2006. Fish, Piquiri River, Upper Paraná River Basin, Paraná State, Brazil. Check List, 2(3): 9-14.

Holzbach, A. J., G. Baumgartner, F. Bergmann, L. B. Rezende Neto, D. Baumgartner, P. V. Sanches \& E. A. Gubiani. 2005. Caracterização Populacional de Steindachnerina insculpta (FernándezYépez, 1948) (Characiformes, Curimatidae) no Rio Piquiri. Acta Scientiarum: Biological Sciences, 27(4): 347-353.

Isaac-Nahum, V. J. \& A. E. A. de M. Vazzoler. 1983. Biologia reprodutiva de Micropogonias furnieri (Desmarest, 1823) (Teleostei, Scianidae), 1. Fator de condição como indicador do período de desova. Boletim do Instituto Oceanográfico, 32(1): 63-69.

Kara, S. 1991. Morfologia ovariana e reprodução dos mandis Iheringichthys labrosus e Pimelodus maculatus (Siluriformes, Pimelodidae) em duas represas da bacia do Paraná superior. Unpublished M.Sc. Dissertation, Universidade Federal de Minas Gerais, Minas Gerais. 129p.

King, M. 1995. Fisheries biology, assessment and management. Oxford, Fishing News Books. 341p.

Kohler, N., J. Casey \& P. Turner. 1995. Length-weight relationships for 13 species of sharks from the western North Atlantic. Fishery Bulletin, 93: 412-418.

Le Cren, E. D. 1951. The lenght-weight relationship and seasonal cycle in gonad weight and conditions in the perch Perca fluviatilis. Journal of Animal Ecology, 20(2): 201-219.

Myers, R. H. 1990. Classical and modern regression with applications. Belmont, Duxbury Press. 488p.

Nakatani, K., G. Baumgartner \& M. Cavicchioli. 1997. Ecologia de ovos e larvas de peixes. Pp. 281-306. In: Vazzoler, A. E. A. de M., A. A., Agostinho \& N. S. Hahn (Eds.). A planície de inundação do alto rio Paraná: Aspectos físicos, biológicos e sócioeconômicos. Maringá, EDUEM. 460p.

Nikolskii, G. V. 1969. Theory of fish population dynamics as the biological background for rational exploitation and management of fishery resources. Edinburgh, Oliver \& Boyd Ltda. 323p.

Paiva, G. V. 1982. Grandes represas do Brasil. Brasília, Editerra. 292p.

Peretti, D. \& I. F. Andrian. 2004. Trophic structure of fish assemblages in five permanent lagoons of the high Paraná River floodplain, Brazil. Environmental Biology of Fishes, 71: 95-103.

Ploskey, G. R. 1985. Impacts of terrestrial vegetation and preimpoundment clearing on reservoir ecology and fisheries in the USA and Canadá. FAO Fisheries Technological Papers, 285. $35 \mathrm{p}$. 
Rezende Neto, L. B. 2004. A fauna de peixes do Rio Piquiri - PR. Unpublished Monographs, Universidade Estadual do Oeste do Paraná, Toledo. 33p.

Rossi-Wongtschowski, C. L. B. 1977. Estudo das variações da relação peso total/comprimento total em função do ciclo reprodutivo e comportamento de Sardinella brasiliensis (Steindachner, 1879) da costa do Brasil entre $23^{\circ} \mathrm{S}$ e $28^{\circ} \mathrm{S}$. Boletim do Instituto Oceanográfico, 26: 131-180.

Santos, E. P. 1978. Dinâmica de populações aplicada à pesca e piscicultura. São Paulo, EDUSP. 130p.

Santos, J. E. dos, N. Bazzoli, E. Rizzo \& G. B. Santos. 2004. Reproduction of the catfish Iheringichthys labrosus (Lütken) (Pisces, Siluriformes) in Furnas reservoir, Minas Gerais, Brazil. Revista Brasileira de Zoologia, 21(2): 193-200.

Silva, Z. 1995. Alimentação natural relacionada a aspectos biológicos e ambientais de Iheringichthys labrosus (Kroeyer, 1874) (Osteichthyes, Siluriformes, Pimelodidae) na represa de Camargos, M.G. Unpublished M.Sc. Dissertation, Universidade Federal de Lavras, Lavras. 96p.

Silva, G. C. da, A. C. L. de Castro \& E. A. Gubiani. 2005. Estrutura Populacional e Indicadores Reprodutivos de Scomberomorus brasiliensis Collette, Russo \& Zavala-Camin, 1978 (Perciformes: Scombridae) no Litoral Ocidental Maranhense. Acta Scientiarum: Biological Sciences, 27(4): 383-389.

Silva, G. C. da, A. C. L. de Castro \& E. A. Gubiani. 2007. Biologia Reprodutiva de Hexanematichthys proops (Valenciennes, 1840) (Siluriformes: Ariidae) no Litoral Ocidental Maranhense. Iheringia, Série Zoologia, 97(4): 498-504.

Stanger, L. H. 2007. Uma contribuição ao Check List da ictiofauna do rio Piquiri, Bacia do rio Paraná. Unpublished Monographs, Universidade Estadual do Oeste do Paraná, Cascavel. 28p.

Vazzoler, A. E. A. de M. 1996. Biologia da reprodução de peixes teleósteos: teoria e prática. Maringá, EDUEM. 169p.

Vazzoler, A. E. A. de M., M. C. Caraciolo-Malta \& S. A. Amadio. 1989. Aspectos biológicos de peixes amazônicos. XII. Indicadores quantitativos do período de desova das espécies do gênero Semaprochilodus (Characiformes, Prochilodontidae) do baixo rio Negro, Amazonas, Brasil. Revista Brasileira de Biologia, 49(1): 175-181.

Zavala-Camin, L. A. 1996. Introdução aos estudos sobre alimentação natural em peixes. Maringá, EDUEM. 129p.

Accepted January 2009

Published March 31, 2009 